\title{
Melatonin and fibroblast growth factor-2 potentiate the effects of human umbilical cord multipotent mesenchymal stromal cells in mice with cuprizone-induced demyelination
}

\author{
I. F. Labunets ${ }^{1}$, NA. Utko ${ }^{1}$, O. K. Toporova ${ }^{1,2}$, S. I. Savosko ${ }^{1}$, Ia. O. Pokholenko ${ }^{1,2}$, \\ T. N. Panteleymonova ${ }^{1}$, G. M. Butenko ${ }^{1}$ \\ ${ }^{1}$ State Institute of Genetic and Regenerative Medicine, NAMS of Ukraine \\ 67, Vyshhorodska Str., Kyiv, Ukraine, 04114 \\ 2 Institute of Molecular Biology and Genetics, NAS of Ukraine \\ 150, Akademika Zabolotnoho Str., Kyiv, Ukraine, 03143 \\ irina_labunets@ukr.net
}

\begin{abstract}
Aim. To study the influence of melatonin and recombinant human fibroblast growth factor (rhFGF-2) on human umbilical cord multipotent mesenchymal stromal cells (hMMSCs) effects at experimental demyelination. Methods. Adult mice were fed with neurotoxin cuprizone for 3 weeks. hMMSCs $\left(5 \times 10^{5}\right.$ cells $)$ were injected on the 10 th day of cuprizone diet. Injections of melatonin or rhFGF-2 were started on the 11th day of cuprizone diet. We used cell culture, flow cytometric, spectrophotometric and histological methods, "open field" and "rotarod" tests. Results. Under the cuprizone influence the motor-, emotional activities and muscle tone decreased. The malondialdehyde (MDA) content in brain increased while the activity of antioxidant enzymes decreased. After injection of hMMSCs the number of crossed squares and grooming activity increased while MDA content decreased. Melatonin and rhFGF-2 injections enhanced the effect of cells on grooming activity and increased the glutathione reductase activity. Melatonin also increased the number of boluses, muscle tone and glutathione peroxidase activity. Conclusion. Melatonin and rhFGF-2 improve the effect of hMMSCs in cuprizonetreated mice. The effects of hMMSCs and melatonin combination is greater than that with rhFGF-2.
\end{abstract}

Keyw or d s: cuprizone, MMSCs, melatonin, FGF-2, behavior, oxidative stress

\section{Introduction}

Multiple sclerosis is a progressing demyelinating, neurodegenerative disease with the locomotor, emotional, autonomic and cognitive disorders. In this disease, the oxidative stress and neuroinflammation factors damage the nerve cells [1]. The transplantation of multi-

(C) 2021 I. F. Labunets et al.; Published by the Institute of Molecular Biology and Genetics, NAS of Ukraine on behalf of Biopolymers and Cell. This is an Open Access article distributed under the terms of the Creative Commons Attribution License (http://creativecommons.org/licenses/by/4.0/), which permits unrestricted reuse, distribution, and reproduction in any medium, provided the original work is properly cited 
potent mesenchymal stromal cells (MMSCs) of various genesis is often used in the treatment of multiple sclerosis $[2,3]$. So, the human umbilical cord MMSCs (hMMSCs) cells are capable of proliferation in vitro, multilinear differentiation, synthesis of anti-inflammatory cytokines and growth factors as well as of immunomodulation $[4,5]$. According to our data, the antioxidant effects of transplanted hMMSCs are combined with the positive behavioural changes in experimental demyelination [6].

It is known that the majority of MMSCs die within three days after their transplantation into pathology-affected organisms [7]. The pineal hormone melatonin influences the survival, differentiation, proliferation and migration of transplanted MMSCs $[8,9]$. Melatonin also exhibits neurotrophic, antioxidant, antiinflammatory, immunomodulatory and antiapoptotic properties $[10,11]$. Noteworthy, the melatonin production by the pineal gland is reduced in the animal multiple sclerosis models whereas the injections of this hormone have neuroprotective and remyelinating effects and improve the central nervous system (CNS) functioning $[12,13]$.

Fibroblast growth factor (FGF-2)/basic FGF reduces the number of brain microglial cells and macrophages and improves the locomotor activity of the animals with induced demyelination $[14,15]$. FGF-2 in the brain promotes proliferation of the neural stem cells (NSCs), inhibits apoptosis of neurons and activates precursors of the myelin-synthesizing cells $[14,16]$. The antioxidant enzymes activity changes under the influence of FGF-2 in animals with pathologies [17]. Besides, the migration, proliferation and differentiation of the
MMSCs changed under the influence of FGF$2[16,18]$.

Our purpose was to study (1) the effects of hMMSCs transplantation on functional and structural CNS changes, oxidative stress and brain's antioxidant defence factors in mice using the model of demyelination (multiple sclerosis); and (2) to assess the possibilities of changing the above effects of these cells using melatonin or FGF-2.

\section{Materials and methods}

Animals. The studies were conducted on 6-7 months old male $129 / \mathrm{Sv}$ mice $\left(\mathrm{H}-2^{\mathrm{b}}\right.$ genotype) $(n=80)$ from the Institute of Genetic and Regenerative Medicine of NAMS of Ukraine (IGRM). The animals were kept under standard conditions with 12:12-h light/dark cycle. Biological material was obtained from animals after euthanasia by decapitation under ether anesthesia. All experimental procedures were carried out in accordance with the European Convention for the Protection of Vertebrate Animals used for experimental and other scientific purposes (Strasbourg, 1986) and were approved by the IGRM Bioethic Commission.

Models. Mice were given neurotoxin cuprizone ([bis(cyclohexanone)-oxaldihydrazone], Sigma, USA) with food daily ( $0.2 \%$ of mass of the daily feed), for three weeks $[1,19]$.

hMMSCs. Human MMSCs were obtained from the umbilical cord of male full-term newborn by explant isolation method. The explants were cultured in DMEM/F12 nutrient medium (Biowest, France) supplemented with $10 \%$ fetal calf serum (HyClone, USA) at $+37{ }^{\circ} \mathrm{C}$ and $5 \% \mathrm{CO}_{2}$. [6]. Second passage hMMSCs have been used for transplantation into ex- 
perimental mice. The population of obtained cells met minimum criteria for hMMSCs as characterized by expression of $\mathrm{CD} 73^{+} / \mathrm{CD} 0^{+} /$ $\mathrm{CD}_{105}{ }^{+}$and the absence of CD45/CD34- cell markers. The MMSCs obtained also showed the ability to differentiate in vitro in a multilinear direction (osteoblasts, chondrocytes and adipocytes). The viability of cells for transplantation was $96 \%$.

hMMSCs were injected once into the tail vein of mice on the 10th day of cuprizone diet at a dose of $5 \cdot 10^{5}$ cells per $50 \mu \mathrm{l}$ of saline. It was found that after 8-10 days of cuprizone treatment there were signs of demyelination and apoptosis of oligodendrocytes in the brain as well as changes in the structure of neurons and in the behavior of mice $[1,20]$.

Melatonin (Sigma, USA) was administered to mice intraperitoneally at 6 p.m. daily at a dose of $1 \mathrm{mg} / \mathrm{kg}$ from the 11th day until the 21 th day of the cuprizone diet.

Recombinant human fibroblast growth factor (rhFGF-2) was obtained from E. coli according to a standard procedure [21]. The proangiogenic activity of rhFGF-2 was assessed by [the] chick chorioallantoic membrane (CAM) assay. RhFGF-2 was injected intraperitoneally $(20 \mu \mathrm{g} / \mathrm{kg})$ starting from the 11th day of cuprizone diet, 8 injections with $48 \mathrm{~h}$ interval.

Groups of mice: Block I: 1 - mice kept on standard diet (intact group); 2 - mice receiving cuprizone and solvent (saline) injections (control group); 3 - mice receiving cuprizone and hMMSCs injection; 4 - mice receiving cuprizone, hMMSCs and melatonin injections. Block II: 1 - mice kept on standard diet (intact group); 2 - mice receiving cuprizone and solvent (saline) injections (control group);
3 - mice receiving cuprizone and hMMSCs injection; 4 - mice receiving cuprizone, hMMSCs and rhFGF-2 injections. Each experimental group contained 10 animals.

This work does not include a group of cuprizone-treated mice, which were injected with melatonin or rhFGF-2 only since these studies were published previously $[12,15]$. However, the common methodological approaches in the previous and present studies allow us to compare the effects of melatonin and rhFGF-2 when administered alone and in combination with hMMSCs.

The behavioral reactions in mice were studied in the "open field" test and rotarod test [12]. In the "open field" test we evaluated: horizontal locomotor, exploratory and emotional activity. All mice were tested for 3 minutes. Rotarod test (test with a rotating cylinder) allowed us to evaluate the motor coordination and balance/muscle tone. The rotation speed was changed sequentially from $10 \mathrm{rpm}$ to $20 \mathrm{rpm}$. Data were presented as total time (s) of keeping the mice on the rod.

Factors of oxidative stress and antioxidant protection were determined, as described previously $[12,20]$. The malondialdehyde (MDA) content in brain homogenate was determined by colour intensity of the trimethine complex formed between thiobarbituric acid and MDA. The antioxidant enzyme activities were measured in the supernatants of brain homogenates by a spectrophotometric assay ( $\mu$ Quant spectrophotometer, Bio-Tek, USA).

For morphologic studies the histological sections of cerebral cortex and hippocampus were stained with toluidine blue. The brain cellular degeneration was calculated as number of injured neurons (picnotic, dark, deformed 
cells) in cortex and per $1000 \mu \mathrm{m}$ by the length of CA1 region of hippocampus. The area of brain neuronal nuclei was calculated in only non-degenerated neurons $\left(\mathrm{mkm}^{2}\right)$.

Statistical analysis of the results was carried out using $t$-student test and Mann-Whitney U-test. Statistica 7.0 software (StatSoft Inc., USA) was used for statistical analysis of the results.

\section{Results}

The effect of hMMSCs and their combination with melatonin on behavior and parameters of brain oxidative stress in cuprizone-treated mice. We found a decrease in the locomotor, emotional and exploratory activities in mice on a cuprizone diet compared with the intact group (Table 1). The number of crossed squares and grooming acts significantly increased after
hMMSCs transplantation compared with the control group, but only grooming acts reached the values of intact mice. After injections of hMMSCs and melatonin the numbers of boluses and grooming were significantly higher than in the group with cells transplantation only and control group. The rotarod retention time in mice treated with hMMSCs and melatonin was practically the same as in intact mice.

After cuprizone treatment the brain MDA content increased and the glutathione peroxidase (GPx) activity decreased as compared with intact values (Table 1). After injection of hMMSCs to cuprizone-treated mice the brain MDA content decreased to the values of intact group. The injections of hMMSCs and melatonin led to a significant decrease in the MDA content compared with control mice. Besides,

Table 1. Indices of behavior and brain oxidative stress in mice of experimental groups, $\mathbf{M} \pm \mathbf{m}$

\begin{tabular}{|l|c|c|c|c|}
\hline \multirow{2}{*}{ Indicator } & \multirow{2}{*}{ Intact group } & \multicolumn{3}{|c|}{ Experimental groups of mice } \\
\cline { 3 - 5 } & & $\begin{array}{c}\text { Cuprizone + saline } \\
\text { (control) }\end{array}$ & $\begin{array}{c}\text { Cuprizone + } \\
\text { + hMMSCs }\end{array}$ & $\begin{array}{c}\text { Cuprizone + hMMSCs + } \\
+ \text { melatonin }\end{array}$ \\
\hline \multirow{3}{*}{ Number of squares } & $72.5 \pm 4.2$ & $28.6 \pm 3.7^{*}$ & $40.8 \pm 3.7^{* \#}$ & $43.5 \pm 5.2^{* \#}$ \\
Number of rearing & $2.1 \pm 0.4$ & $1.1 \pm 0.2^{*}$ & $1.0 \pm 0.1^{*}$ & $0.9 \pm 0.2^{*}$ \\
Number of boluses & $2.5 \pm 0.3$ & $0.7 \pm 0.1^{*}$ & $0.5 \pm 0.1^{*}$ & $1.5 \pm 0.3^{* \# \&}$ \\
Number of "holes" & $2.3 \pm 0.3$ & $0.6 \pm 0.1^{*}$ & $0.6 \pm 0.2^{*}$ & $0.5 \pm 0.1^{*}$ \\
Number of grooming acts & $0.4 \pm 0.1$ & $0.2 \pm 0.01^{*}$ & $0.4 \pm 0.1^{\#}$ & $0.7 \pm 0.1^{\# \&}$ \\
Remained on a rod, s & $105.5 \pm 12.2$ & $72.5 \pm 8.4^{*}$ & $65.6 \pm 13.5^{*}$ & $88.5 \pm 15.1$ \\
& Oxidative stress in the brain & & \\
Malondialdehyde, $\mathrm{nmol} / \mathrm{mg}$ & $4.5 \pm 0.5$ & $7.3 \pm 0.8^{*}$ & $4.6 \pm 0.3^{\#}$ & $5.1 \pm 0.6^{\#}$ \\
Superoxide dismutase, $\mathrm{U} / \mathrm{mg} \cdot \mathrm{min}$ & $14.6 \pm 0.8$ & $15.4 \pm 0.8$ & $15.8 \pm 0.6$ & $16.4 \pm 0.6$ \\
Catalase, $\mu$ mol/mg·min & $0.9 \pm 0.2$ & $0.8 \pm 0.1$ & $1.0 \pm 0.2$ & $0.8 \pm 0.1$ \\
Glutathione peroxidase, $\mathrm{nmol} / \mathrm{mg} \cdot \mathrm{min}$ & $7.8 \pm 0.5$ & $4.4 \pm 0.3^{*}$ & $5.5 \pm 0.3^{*}$ & $6.8 \pm 0.4^{*}$ \\
Glutathione reductase, $\mathrm{nmol} / \mathrm{mg} \cdot \mathrm{min}$ & $17.5 \pm 1.0$ & $17.7 \pm 0.9$ & $17.8 \pm 2.2$ & $22.8 \pm 1.8^{* \#}$ \\
\hline
\end{tabular}

Note: here and in table $2: \mathrm{p}<0.05: *$-vs intact group; \# -vs control group; \& - vs mice receiving cuprizone+hMMSCs 
the activity of GPx was higher than in the group with only cells injection and the glutathione reductase (GR) activity exceeded those of control and intact groups.

Thus, hMMSCs transplantation positively affected some altered behavior parameters and the brain MDA content in cuprizone-treated mice. The melatonin injections after hMMSCs transplantation enhanced their effect on the behavior reactions and led to the positive changes of the behavior parameters, which remained unchanged after injection of hMMSCs alone. The behavior improvement was coincident with the MDA content decrease and increase of brain antioxidant defence.

The effect of hMMSC+rhFGF-2 on behavior and brain oxidative stress in cuprizone-treated mice. The hMMSCs injection into cuprizone-treated mice led to a significant increase in the number of crossed squares and grooming compared with control mice (Table 2). After injections of hMMSCs and rhFGF-2 the number of groomings exceeded that not only in the control mice but also the in animals receiving hMMSCs alone.

The MDA content in the brain of cuprizonetreated mice with both the injection of hMMSCs and their combination with rhFGF-2 decreased to the values of intact mice (Table 2). The injections of cells and rhFGF-2 resulted in an increase of brain GR activity compared with the hMMSCs-treated mice.

Thus, injections of rhFGF-2 following hMMSCs transplantation enhanced their effects on the groomings in cuprizone-treated mice. This was combined with decreased MDA content and increased brain GR activity.

The effect of combination of hMMSCs and melatonin or rhFGF-2 on the structural changes in CNS of cuprizone-treated mice.

Table 2. Indices of behavior and brain oxidative stress in mice of experimental groups, $\mathbf{M} \pm \mathbf{m}$

\begin{tabular}{|l|c|c|c|c|}
\hline \multirow{2}{*}{ Indicator } & \multirow{2}{*}{ Intact group } & \multicolumn{3}{|c|}{ Experimental groups of mice } \\
\cline { 3 - 5 } & & $\begin{array}{c}\text { Cuprizone + saline } \\
\text { (control) }\end{array}$ & $\begin{array}{c}\text { Cuprizone }+ \\
+ \text { hMMSCs }\end{array}$ & $\begin{array}{c}\text { Cuprizone + } \\
+ \text { hMMSCs + rhFGF-2 }\end{array}$ \\
\hline \multirow{3}{*}{ Number of squares } & $69.2 \pm 5.2$ & $16.5 \pm 1.9^{*}$ & $39.0 \pm 3.4^{* \#}$ & $25.5 \pm 6.8^{*}$ \\
Number of rearing & $1.3 \pm 0.3$ & $0.5 \pm 0.2^{*}$ & $0.5 \pm 0.2^{*}$ & $0.4 \pm 0.1^{*}$ \\
Number of boluses & $2.2 \pm 0.3$ & $0.1 \pm 0.01^{*}$ & $0.1 \pm 0.01^{*}$ & $0.1 \pm 0.02^{*}$ \\
Number of "holes" & $2.0 \pm 0.3$ & $0.4 \pm 0.1^{*}$ & $0.3 \pm 0.1^{*}$ & $0.3 \pm 0.1^{*}$ \\
Number of grooming acts & $0.5 \pm 0.1$ & $0.1 \pm 0.01^{*}$ & $0.3 \pm 0.02^{\#}$ & $0.8 \pm 0.2^{\# \&}$ \\
Remained on a rod, s & $110.1 \pm 13.2$ & $66.8 \pm 14.2^{*}$ & $60.5 \pm 18.6^{*}$ & $61.0 \pm 15.5^{*}$ \\
& Oxidative stress in the brain & & \\
Malondialdehyde, $\mathrm{nmol} / \mathrm{mg}$ & $3.7 \pm 0.3$ & $7.8 \pm 0.5^{*}$ & $3.3 \pm 0.3^{\#}$ & $3.4 \pm 0.4^{\#}$ \\
Superoxidedismutase, $\mathrm{U} / \mathrm{mg} \cdot \mathrm{min}$ & $12.2 \pm 0.9$ & $11.9 \pm 0.8$ & $12.5 \pm 0.6$ & $13.2 \pm 0.7$ \\
Catalase, $\mu$ mol/mg $\cdot \mathrm{min}$ & $0.8 \pm 0.1$ & $0.9 \pm 0.1$ & $1.2 \pm 0.2$ & $0.9 \pm 0.2$ \\
Glutathione peroxidase, $\mathrm{nmol} / \mathrm{mg} \cdot \mathrm{min}$ & $7.1 \pm 0.4$ & $5.5 \pm 0.3^{*}$ & $5.3 \pm 0.4^{*}$ & $6.1 \pm 0.2^{*}$ \\
Glutathione reductase, $\mathrm{nmol} / \mathrm{mg} \cdot \mathrm{min}$ & $15.6 \pm 1.7$ & $14.8 \pm 1.5$ & $14.6 \pm 1.3$ & $19.2 \pm 1.8^{*}$ \\
\hline
\end{tabular}


A large number of dead (degenerated) neurons were detected in the cerebral cortex and CA1 region of stratum pyramidale in all experimental groups compared with intact mice (Fig. 1).

The morphometric analysis of non-degenerated brain neurons revealed a significant

A

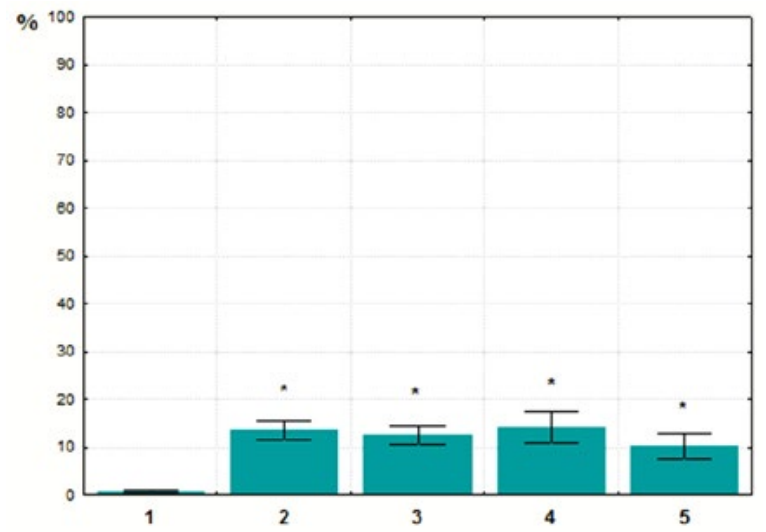

increase in the area of nuclei after the use of cuprizone (Fig. 2).

According to our earlier data, an increase of the area of CNS neurons may be a manifestation of their reactive changes to toxic influence of cuprizone [20]. In current study, the

$\boldsymbol{B}$

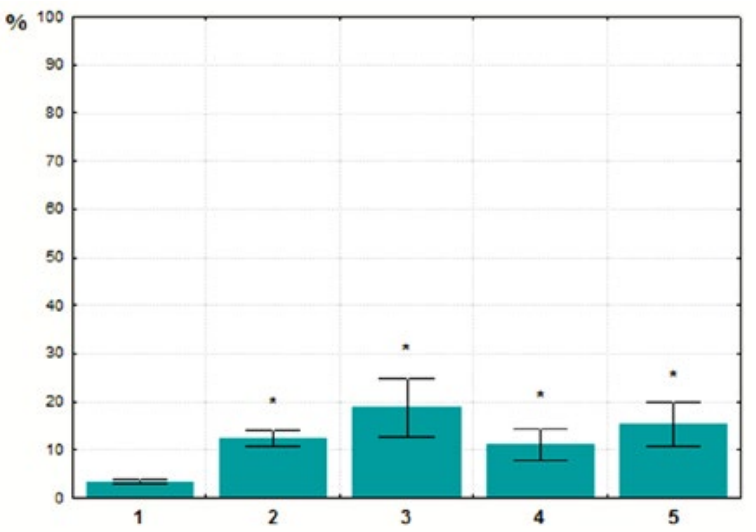

Fig. 1. The density of degenerated neurons in cerebral cortex $(\boldsymbol{A})$, CA1 zone of hippocampus $(\boldsymbol{B})$ in experimental groups of mice $(1$ - intact mice; 2 - cuprizone (control group); 3 - cuprizone+hMMSCs group; 4 cuprizone+hMMSCs+melatonin group; 5 - cuprizone+hMMSCs + rhFGF-2 group, ${ }^{*}-\mathrm{P}<0.05$ vs intact group
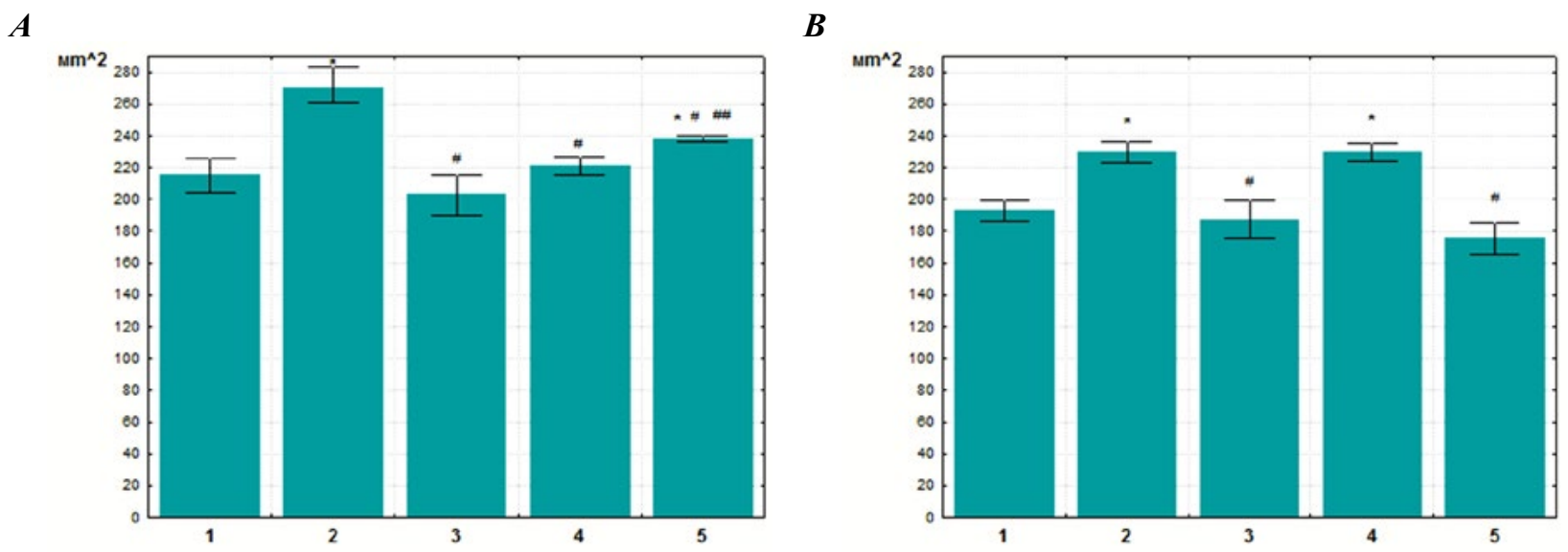

Fig. 2. Area of the nucleus of non-degenerated neurons in the cerebral cortex $(\boldsymbol{A}), \mathrm{CA} 1$ zone of hippocampus $(\boldsymbol{B})$ in experimental groups of mice (1 - intact mice; 2 - cuprizone (control group); 3 - cuprizone+hMMSCs group;4 cuprizone+ hMMSCs + melatonin group; 5 - cuprizone+hMMSCs + rhFGF-2 group. ${ }^{*}-\mathrm{P}<0.05$ vs intact group; \# - $\mathrm{P}<0.05$ vs control group; \#\# — vs cuprizone+hMMSCs+melatonin group 
area of nuclei of non-degenerated neurons in cortex and hippocampus after injection of hMMSCs was similar to that of intact mice. So, transplantation of hMMSCs can reduce the structural changes of neurons in cerebral cortex and hippocampus of cuprizone-treated mice. The similar structural changes in the brain demonstrated the combination of hMMSCs with melatonin (cerebral cortex), and with rhFGF-2 (cortex and hippocampus). However, the changes of indices in brain cortex in case of the cell with melatonin combination were greater than those in case of the cell combination with rhFGF-2.

\section{Discussion}

\section{Influence of hMMSCs transplantation on the} behavior and oxidative stress in the brain of cuprizone-treated mice Transplantation of hMMSCs to the cuprizone-treated mice decreased the MDA content in brain and caused certain positive morpho-functional changes in CNS. Our morphological data are consistent with the results of other authors [22]. The antioxidant properties of hMMSCs in the demyelinating pathology were shown in $[1,23]$. Anti-inflammatory properties of hMMSCs may be also important in their positive effects in cuprizone-treated mice. Thus, cuprizone led to imbalances in pro- and anti-inflammatory cytokines and activation of macroglia cells in the brain $[1,12,20]$. However, after the injection of hMMSCs to the animals with demyelinating pathology, a decrease in reactive gliosis in the brain and behavior improving were established [6, 24].

Effects of hMMSC+melatonin administration to cuprizone-treated mice. Because in the current work the changes of some indices of behavior in the group with hMMSCs + melatonin were similar to those in the cuprizonetreated mice injected only with melatonin [12], it was possible to suggest their connection with the influence of hormone alone. Thus, melatonin affects the viability, proliferation and differentiation of NSCs and increases brain-derived neurotrophic factor expression, the number of differentiating neuroblasts in the brain, which reduced under the influence of cuprizone [25]. We also revealed activation of neurogenesis and myelinogenesis in the brain of cuprizone-treated mice after injections of melatonin $[12,19]$. In the current study, we observed a positive effect of the hMMSCs on melatonin combination to the reactive changes of nondegenerated neurons in cerebral cortex.

According to the data of Anderson and coauthors [26], the antioxidant and anti-inflammatory properties of melatonin are important for its therapeutic effect in demyelinating pathology of CNS. In the current work we observed the activation of brain antioxidant enzymes only in the mice injected with hMMSCs and melatonin. Our earlier results showed the behavior improvement, activation of neurogenesis, and a decrease in the MDA content, the number of macrophages in the brain of cuprizone-treated mice after melatonin injection [12].

It is a known fact that about $80 \%-90 \%$ of MMSCs die within 72 hours after transplantation, which is connected with the influence of oxidative stress, neuroinflammation and hypoxia in damaged tissues [7]. Melatonin protects MMSCs against apoptosis by acting as a scavenger of free radicals, activating gene expression of antioxidant enzymes, and inhibiting the production of tumor necrosis factor- $\alpha$ and IL-6 in MMSCs [7, 8]. Additionally, me- 
latonin enhances the migration of MMSCs into the damaged area and their effects on the neurogenesis in CNS pathology [9, 27]. Apparently, the above-mentioned properties of melatonin may explain the enhancement of positive effects of hMMSCs in cuprizone-treated mice after injections of cells and melatonin.

Effects of hMMSCs +rhFGF-2 administration to cuprizone-treated mice. In this experiment, injections of the cells with rhFGF-2 improve the emotional activity (grooming) of cuprizone-treated mice. One of the possible pathways for positive influence of FGF-2 in CNS pathology is the change in the number and/or activity of neuroinflammatory cells and [the] antioxidant effect $[17,28]$. According to our earlier data, the amount of active macrophages in the brain of cuprizone-treated mice decreased after injections of rhFGF-2 [15]. In the current work, the use of hMMSCs in combination with rhFGF-2 led to an increased brain GR activity in such mice.

The effects of combined administration of hMMSCs+melatonin or +rhFGF- 2 in cuprizone-treated mice, had common features and some peculiarities. The common feature was the enhancement of hMMSCs effects on the grooming frequency and GR activity in the brain. It was found that melatonin increased the b-FGF production by the MMSCs in animals with CNS pathology [27]. This is most likely why we observed unidirectional changes in some indices when using a combination of hMMSCs with melatonin as well as with rhFGF-2. The particular feature of the effects of injection of cells with melatonin consists in more pronounced positive changes in the behavior and antioxidant protection in the brain of cuprizone-treated mice.

\section{Conclusion}

Transplantation of the hMMSCs has a positive impact on the morpho-functional changes in CNS and manifestations of oxidative stress in the brain of adult mice with the cuprizone model of demyelination. The injections of melatonin or rhFGF-2 after the hMMSCs transplantation improve the therapeutic effect of the cells in cuprizone-treated mice. The effects of hMMSCs and melatonin combination on behavioral responses and brain antioxidant protection is greater than that of the cells with rhFGF-2. The research results can be useful in the development of approaches to the cell therapy for demyelinating pathology.

\section{REFERENCES}

1. Praet J, Guglielmetti C, Berneman Z, Van det Linden A, Ponsaerts P. Cellular and molecular neuropathology of the cuprizone mouse model: Clinical relevance for multiple sclerosis. $J$ Neubiorev. 2014; 47:485-505.

2. Genc B, Bozan HR, Genc S, Genc K. Stem cell therapy for multiple sclerosis. Adv Exp Med Biol. 2019; 1084:145-74.

3. Sarcar P, Rice CM, Scolding NJ. Cell therapy for multiple sclerosis. CNS Drugs. 2017; 31:453-69.

4. Can A, Celikkan FT, Cinar O. Umbilical cord mesen-chymal stromal cell transplantation: a systemic analysis of clinical trials. Cytotherapy. 2017; 19(12):1351-82.

5. Putra A, Ridwan BR, Putridewi AI, Kustiyah AR, Wirastuti K, Sadyah NA, Rosdiana I, Muni D. The role of TNF-alpha induced MSCs on suppressive inflammation by increasing TGF-beta and IL-10. Open Access Maced J Med Sci. 2018; 6(10):1779-83.

6. Labunets I, Utko N, Toporova O, Panteleymonova T, Rodnichenko A, Butenko $G$. The effects of human umbilical cord multipotent mesenchymal stromal cells on the behaviour and oxidative stress in the brain of mice of different ages with a cuprizone- 
induced model of demyelination. Cell and Organ Transplantology. 2020; 8(1):38-42.

7. Luchetti F, Canonico B, Bartolini D, Arcangeletti M, Ciffolilli S, Murdolo G, Piroddi M, Papa S, Reiter $R J$, Galli $F$. Melatonin regulates mesenchymal stem cell differentiation: a review. J Pineal Res. 2014; 56:382-97.

8. Hu Ch, Li L. Melatonin plays critical role in mesenchymal stem cell-based regenerative medicine in vitro and in vivo. Stem Cell Res Ther. 2019; 10:13.

9. Zhang S, Chen $S$, Li Y, Liu Y. Melatonin as a promi-sing agent of regulatory stem cell biology and its application in disease therapy. Pharmacol Res. 2017; 117:252-60.

10. Manchester LC, Coto-Montes A, Boga JA, Andersen LPH, Zhou Z, Galano A, Vriend J, Tan D-X, Reiter RJ. Melatonin: an ancient molecule that makes oxygen metabolically tolerable. J Pineal Res. 2015; 59(4):403-19.

11. Sarlak G, Jenwitheesuk A, Chetsawang B, Govitrapog $P$. Effects of melatonin on nervous system aging: neurogenesis and neurodegeneration. $J$ Pharmacol Sci. 2013; 123(1):9-24.

12. Labunets IF, Rodnichenko AE. Melatonin effects in young and aging mice with the toxic cuprizone-induced demyelination. Adv gerontol. 2020; 10(1):41-9.

13. Wurtman R. Multiple sclerosis, melatonin and neurobehavioral diseases. Front Endocr. 2017; 8:280.

14. Rottlaender A, Villwock $H$, Addicks K, Kuerten $S$. Neuroprotective role of fibroblast growth factor-2 in experimental autoimmune encephalomyelitis. Immumology. 2011; 133(3):370-8.

15. Labunets I, Rodnichenko A, Utko N, Panteleimonova T, Pokholenko Ya, Litoshenko Z, Butenko G. Effects of interleukin-10 and fibroblasts growth factor 2 in mice with toxic cuprizone model of demyelination. Cell and organ transplantology. 2019; 7(1): 25-31

16. Huang Y, Dreyfusm ChF. The role of growth factors et a therapeutic approach to demyelinating disease. Exp Neurol. 2016; 283(PtB):531-40.

17. Wang L, Li Xi-Xi, Chen Xi, Qin X-Y, Kardami E, Cheng $Y$. Anti-depresant-like effects of low- and high molecular weight FGF-2 on hronic unpredictable mild stress. Front Mol Neurosci. 2018; 11:377.
18. Coutu DL, Galipeau J. Roles of FGF signaling in stem cell self-renewal, senescence and aging. Aging. 2011; 3(10):920-33.

19. Labunets IF. Possibilities and prospects of the application of the in vivo and in vitro toxic cuprizone model for demyelination in experimental and clinical neurology (literature review and own research results). Ukr Neurol J. 2018; 2:63-8.

20. Labunets IF, Rodnichenko AE, Melnyk NO, Rymar SE, Utko NA, Gavrulyk-Skyba GO, Butenko GM. Neuropro-tective effect of the recombinant human leukemia inhibitory factor in mice with an experimental cuprizone model of multiple sclerosis: possible mechanisms. Biopolym Cell. 2018; 34(5):350-60.

21. The Protein Protocols Handbook. Ed. JM Walker. Totowa, New Jersey: Humana Press Inc., 2002. 1139 p.

22. Semenova VM, Tsymbalyuk VI, Liubich LD, Egorova DM, Stayno LP, Shevchuk OV, Vaslovich VV, Verbovska SA, Deryabina OG, Shuvalova NS, Pichkur $L D$. Structural changes in the brain of rats with experimental allergic encephalomyelitis after cryopreserved mesenchymal stem cells impact. World Med Biol. 2020;74(4):199-204.

23. Wojtas E, Zachwieja A, Zwyrzykowska A, Kupczynski $R$, Marycz $K$. The application of mesenchymal progenitor stem cells in the reduction of oxidative stress in animals. Turk J Biol. 2017; 41:12-19.

24. Mukai T, Mon Y, Shimazu T, Takahashi A, Tsunoda H, Yamaquchi S,Koryu Sh, Tojo A, NagamuraInoue $T$. Intravenous injection of umbilical cordderived mesenchymal stromal cells attrnuates reactive gliosis and hypo-myelination in neonatal intraventricular hemorrhage model. Neuroscience. 2017; 355:175-87.

25. Kim W, Hahn KR, Jung H, Kwon HJ, Nam SM, Kim JW, Park J, Yoo DY, Kim DW, Won M-H, Yoon Y, Hwang I. Melatonin ameliorates cuprizone-induced reduction of hippocampal neurogenesis, brain-derived neurotrophic factor, and phosphorylation cyclic AMP response element-binding protein in the mouse dentate gyrus. Brain Behav. 2019; 9(9): eo1388.

26. Anderson G, Rodriguez M. Multiple sclerosis:the role of melatonin and $\mathrm{N}$-acethylserotonin. Multiple sclerosis and related disorders. 2015; 4(2):112-23. 
27. Tang V, Cai B, Yuan F, He X, Lin X, Wang J, Wang Y, Yang $G Y$. Melatonin pretreatment improves the survival and function of transplanted mesenchymal stem cells after focal cerebral ischemia. Cell Transplantation. 2014; 23(10):1279-1.

28. Woodbury ME, Ikezu T. Fibroblast growth factor-2 signaling in neurogenesis and neurodegeneration. J Neuroimmune Pharmacol. 2014; 9(2):92-101.

\section{Мелатонін і фактор росту фібробластів-2 посилюють ефекти мультипотентних мезенхімальних стромальних клітин пуповини людини у мишей із купризоновою моделлю деміслінізації \\ І. Ф. Лабунець, Н. О. Утко, О. К. Топорова, С. І. Савосько, Я. О. Похоленко, \\ Т. М. Пантелеймонова, Г. М. Бутенко}

Мета. Дослідити вплив мелатоніну і рекомбінантного фактору росту фібробластів-2 людини (rhFGF-2) на ефекти мультипотентних мезенхімальних стромальних клітин пуповини людини (ММСК-П) при експерименталь ній демієлінізації. Методи. Дорослі миші отримували нейротоксин купризон впродовж 3 тижнів. ММСК-П (5х105 клітин) вводили на 10 день купризонової дієти, мелатонін або rhFGF-2 - 3 11-го дня прийому купризону. Використовувалися стандарнтні методики культуральні, спектрофотометричні, проточної цитометрії, гістологічні, тест «відкрите поле» і «ротарод тест». Результати. Під впливом купризону зменшувалась рухова, емоційна активність і м'язовий тонус; у головному мозку зростав вміст малонового діальдегіду (МДА) і падала активність антиоксидантних ферментів. Після введення ММСК-П число пересічених квадратів і вмивань підвищувалось, а вміст МДА зменшувався. Ін'єкції мелатоніну і rhFGF-2 посилювали ефект клітин на число вмивань і підвищували активність глютатіонредуктази. Мелатонін також підвищував число болюсів, м'язовий тонус і активність глютатіонпероксидази. Висновки. Мелатонін і rhFGF-2 покращували ефекти ММСК-П у мишей із купризоновою дієтою. Ефект комбінації клітин з мелатоніном виразніший, ніж із rhFGF-2.
К л юч о в і с л о в а: купризон, ММСК, мелатонін, FGF-2, поведінка, оксидативний стрес

\section{Мелатонин и фактор роста фибробластов-2 усиливают эффекты мультипотентных мезенхимальных стромальных клеток пуповины человека у мышей с купризоновой моделью демиелинизации}

И. Ф. Лабунец, Н. А. Утко, Е. К. Топорова, С. И. Савосько, Я. О. Похоленко, Т. Н. Пантелеймонова, Г. М. Бутенко

Цель. Исследовать влияние мелатонина и рекомбинантного фактора роста фибробластов-2 человека (rhFGF-2) на эффекты мультипотентных мезенхимальных стромальных клеток пуповины человека (ММСК-П) при экспериментальной демиелинизации. Методы. Взрослые мыши получали нейротоксин купризон в течение 3 недель. ММСК-П (5х105 клеток) вводили на 10 день купризоновой диеты, мелатонин или rhFGF-2 - с 11-го дня приема купризона. Также использовались стандартные методы культуральной работы, спетрофотометрия, проточной цитометрия, гистологии, тест «открытое поле» и «ротарод тест». Результаты. Под влиянием купризона уменьшалась двигательная, эмоциональная активность и мышечный тонус; в головном мозге росло содержание малонового диальдегида (МДА) и падала активность антиоксидантных ферментов. После введения ММСК-П число пересеченных квадратов и умываний повышалось, а содержание МДА уменьшалось. Инъекции мелатонина и rhFGF-2 усиливали эффект клеток на число умываний и повышали активность глютатионредуктазы. Мелатонин также повышал число болюсов, мышечный тонус и активность глютатионпероксидазы. Выводы. Мелатонин и rhFGF-2 улучшали эффекты ММСК-П у мышей с купризоновой диетой. Эффект комбинации клеток с мелатонином значительнее, чем с rhFGF-2.

К л ю ч е в ы е с л о в а: купризон, ММСК, мелатонин, FGF-2, поведение, оксидативный стресс

Received 10.08.2021 